\title{
A Triumph of Liberalism: The Supreme Court of Canada AND THE EXCLUSION OF EVIDENCE
}

\author{
JULIANNE PARFETT*
}

The common law has historically defined selfincrimination narrowly. Using Packer's models of the criminal justice system as a framework. the article examines the Supreme Court of Canada's interpretations of s. 24(2) of the Charter. The Court has expanded the definitions of both selfincrimination and remoteness. The author argues that s. 24(2) has ceased to be a remedy requiring the balancing of interests and has become a quasiautomatic rule of exclusion, which promotes individual rights at the cost of victim's rights. Further, in the Court's zeal to protect the integrity of the system, there is no allowance made for the seriousness of the breach, the consequences of the exclusion, or the causal connection between the breach and any evidence obtained. The author argues that this has resulted in a justice system more concerned with police behaviour than with the pursuit of truth. Instead, either the exclusionary rule must be used to foster a balance of individual and communitarian rights, or other more imaginative remedies should be crafted from s. 24(2) 10 protect the integrity of the legal system.
Historiquement, le droit commun définit très étroitement le témoignage contre soi-méme. Prenant les modèles Packer comme cadre du système de justice pénale, l'article examine l'interprétation faite par la Cour Supreme du Canada du paragraphe 24(2) de la Charte. La Cour a élargi les définitions à la fois du témoignage contre soi-mème et du caractère indirect. Selon l'auteur, le paragraphe 24(2) a cessé d'être un remède exigeant de balancer les intérèts pour devenir une norme quasi automatique de la règle d'exclusion; laquelle promeut les droits individuels au détriment des droits de la victime. De plus, soucieuse de préserver l'intigrité du système, la Cour ne fait aucune provision quant à la gravité du délit (conséquences de l'exclusion) ou le rapport de causalité entre l'infraction et la preuve obtenue. L'auteur fait valoir que ceci a eu pour conséquence un système judiciaire plus préoccupé par le comportement des forces policières que par la recherche de la vérité. Au lieu de cela, la règle d'exclusion doit ètre utilisée pour maintenir l'éguilibre entre les droits de l'individu et ceux de la communauté; ou d'autres remèdes inédits doivent ètre tirés du paragraphe 24(2) afin de préserver l'intégrité du système judiciaire.

\section{TABLE OF CONTENTS}

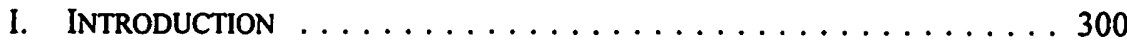

II. THEORETICAL FRAMEWORKS $\ldots \ldots \ldots \ldots \ldots \ldots \ldots \ldots \ldots \ldots \ldots$

A. A Model of the CRIMINAL Justice SySTEM $\ldots \ldots \ldots \ldots 301$

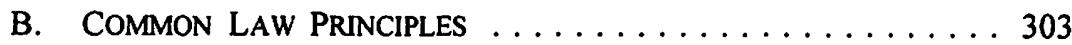

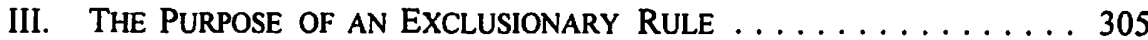

A. VINDICATION OF ACCUSED'S RIGHTS $\ldots \ldots \ldots \ldots \ldots \ldots 306$

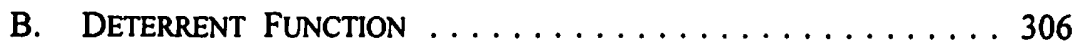

C. INTEGRITY OF THE SYSTEM $\ldots \ldots \ldots \ldots \ldots \ldots \ldots \ldots 308$

IV. THE DEVELOPMENT OF THE EXCLUSIONARY RULE $\ldots \ldots \ldots \ldots 311$

A. THE ADMISSION OF THE EVIDENCE WOULD

AFFECT THE FAIRNESS OF THE TRIAL $\ldots \ldots \ldots \ldots \ldots \ldots 311$

B. EVIDENCE OBTAINED IN A MANNER THAT

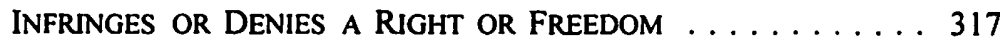

Assistant Crown Attomey, Ottawa, Ontario. 

C. EVIdence That Would BRING the

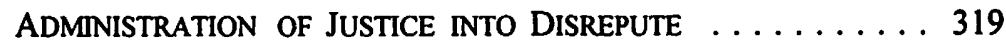
D. Alternatives to THE PRESENT RULE $\ldots \ldots \ldots \ldots \ldots \ldots 321$

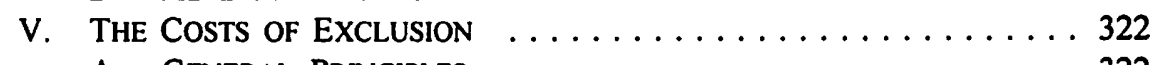

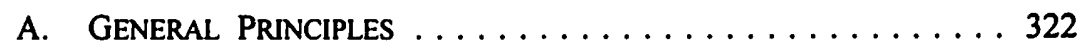

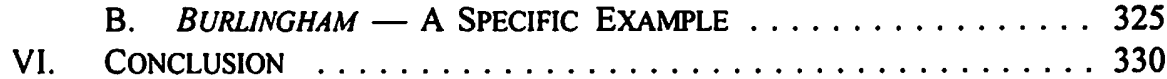

\title{
I. INTRODUCTION
}

The Charter of Rights and Freedoms ${ }^{1}$ was proclaimed in force on 15 April 1982. Since that time, one of the most fruitful areas of litigation concerning the Charter has been its remedial section, s. 24(2), which reads,

\begin{abstract}
Where, in proceedings under subsection (1), a court concludes that evidence was obtained in a manner that infringed or denied any rights or freedoms guaranteed by the Charter, the evidence shall be excluded if it is established that, having regard to all the circumstances, the admission of it in the proceedings would bring the administration of justice into disrepute.
\end{abstract}

Originally conceived as a compromise between what was perceived to be the automatic exclusionary rule in the United States, and the Canadian common law rule which permitted admission of the evidence regardless of the manner in which it was obtained, the exclusionary rule has in fact developed into a quasi-automatic exclusionary rule.

This article takes as its starting point the idea that the development of the Canadian exclusionary rule is reflective of a particular legal philosophy: liberalism. The definition of liberalism used here is taken from F.C. DeCoste's, "A Review of Canadian Perspectives on Legal Theory." It is a comprehensive, if complex, definition of liberalism and its relationship to legal theory:

[L]iberalism ineluctably frames its theory of civil society (namely, that it antedates political organization), and its theory of government (namely, that it is necessary to solve the co-ordination problems which inhere naturally in civil society, and that it is necessarily itself a problem because it threatens always, through paternalism, to contradict the protection of autonomy which is its intended purchase); and from these claims regarding the inherent tension between civil society and political organization, liberalism just as ineluctably frames its theory of law (namely, that law is always merely a strategy directed towards a prior natural social ontology, and never a constitutive cultural practice), and its theory of the (proper) state (namely, that because political organization threatens always paternalism through law, the proper state is a minimal state, and a properly minimal state is one limited by constitutional provision which pledges the state to neutrality and, thereby, prohibits it from intruding on individual autonomy - which, finally, is the ontological predicate from which the entire politico-legal claim arises). ${ }^{2}$ 
Put more simply, liberalism as a legal theory posits two opposing forces: the individual and the state. Constitutional jurisprudence is an effort to preserve the autonomy of the individual and curb the paternalism of the state. Using this approach, the criminal justice system can be seen as a dialectic between the individual, who seeks to preserve his or her privacy, and the state, which seeks information with which to prosecute criminal offences.

This liberalism is expressed both explicitly and implicitly in the decisions of the Supreme Court of Canada. The Supreme Court's statements concerning the purpose of s. 24(2), the establishment of the factors to be considered in applying the test of whether the admission of evidence would affect the reputation of the administration of justice, and its definition of self-incrimination have all contributed to the development of a quasi-automatic rule of exclusion that has negated the balancing of interests that s. 24(2) itself requires. This approach to the rule has prevented the courts from considering broader communitarian interests.

This article criticizes the Supreme Court's approach to the exclusionary rule. It argues that the Supreme Court's legal liberalism has resulted in a narrow definition of the interests that figure in the criminal justice system and has effectively ignored victims' rights. It suggests that the Supreme Court of Canada should have developed a test for exclusion that uses a more communitarian approach, one which takes into consideration victims' rights and the needs of the administration of justice as a whole. Finally, it argues that the Supreme Court's approach requires victims to pay a high price for the protection of individual rights.

\section{Theoretical Frameworks}

In order to understand how the Supreme Court has come to create the exclusionary rule, it is necessary to understand two quite separate paradigms that influenced the approach that the Court has taken to the interpretation of s. 24(2). The first paradigm is a model of criminal justice that is based on legal liberalism and which, it is suggested, reflects the perception that the Supreme Court has of the criminal justice system. The second paradigm is the common law understanding of the interplay between the confessions rule, the privilege against self-incrimination, and the right to silence.

\section{A. A Model of The CRiminal Justice SyStem}

The legal theory of Herbert Packer is reflective of a liberalist philosophy. ${ }^{3}$ He sees society as composed of two competing spheres of influence. The private (individual) sphere competes with the public (state) sphere. Individuals carve out spheres of undiluted power from the overarching power of the government. ${ }^{4}$ Individuals always seek to minimize the influence of government, because freedom is defined as freedom

H.L. Packer, "The Courts, The Police and The Rest of Us" (1966) 57 J. Crim. L.C. \& P.S. 238. L.R. Katz, "Reflections on Search and Seizure and Illegally Seized Evidence in Canada and the United States" (1980) 3 Can.-U.S. L.J. 103 at 109. 
from government control. ${ }^{5}$ This theory ignores collective rights and is focused exclusively on the dialectic between the state and the individual. ${ }^{6}$ The impact of this perspective is to elevate the protection of individual privacy to a position of supremacy. The truth-seeking function of the criminal court is thereby relegated to a place of secondary importance. " As noted in Katz's article, "Reflections on Search and Seizure and Illegally Seized Evidence in Canada and the United States,"

[t]he linchpin of the American approach [to the treatment of fundamental rights in the courts] is the exclusionary rule. The rule had its seeds in the nineteenth century and was judicially formalized in the United States in the twentieth century. The Supreme Court applied the exclusionary rule to criminal prosecutions in federal courts in 1914. The rule was made binding upon prosecutions in state criminal courts in 1961. ${ }^{8}$

Katz also notes that the exclusionary rule is a peculiarly American institution. ${ }^{9}$ Although other common law jurisdictions have rules for the exclusion of evidence in some circumstances, ${ }^{10}$ only the United States has developed a rule which has as its starting point the fact that evidence obtained in breach of constitutional rights must be excluded, unless it can be shown that the evidence comes within certain enumerated exceptions."

Packer developed his theory to explain the evolution of criminal jurisprudence in the United States. ${ }^{12}$ His model incorporates two premises: due process and crime control. The due process premise can be defined as any decision that has a tendency to emphasize individual rights, usually at the expense of both administrative efficiency and the truth-seeking function of the trial. ${ }^{13}$ The crime control premise can be defined as any decision that tends to increase the truth-seeking purpose of the trial, thereby increasing efficiency in the process. However, this administrative efficiency usually comes at the expense of individual rights. ${ }^{14}$ There are a number of limitations inherent in Packer's theory. The first limitation is Packer's assumption that the criminal justice system performs a crime control function. There is very little empirical evidence that the criminal justice system per se has any impact on crime rates. ${ }^{15}$ The origins of criminal behaviour are too complex to permit the conclusion that the criminal justice system performs a crime control function. The second limitation of Packer's theory is

Ibid. at 104. See also K.E. Mahoney, "The Limits of Liberalism" in R.F. Devlin, ed., Canadian Perspectives on Legal Theory (Toronto: Emond Montgomery, 1991) 61.

Katz, ibid. at 106.

lbid.

Ibid. at 105 [footnotes omitted].

Ibid. at 106.

S.M. Penney, "Unreal Distinctions: The Exclusion of Unfairly Obtained Evidence Under s. 24(2) of the Charter" (1994) 32 Alta. L. Rev. 782, online: QL (JOUR) at 3-11.

K. Roach, Due Process and Victims' Rights: The New Law and Politics of Criminal Justice (Toronto: University of Toronto Press, 1999) at 7.

lbid.

Ibid. at 13 .

Ibid.

K. Jull, "Remedies for Non-Compliance with Investigative Procedures: A Theoretical Overview" (1985) 17 Ottawa L. Rev. 525 at 536. 
that the theory has only a narrow application. The theory creates a bipolar model that ignores any other competing interests in the criminal justice system. Victims of crime and the communities of both victims and perpetrators of crime all have an interest in the criminal justice process. ${ }^{16}$ The advantage of Packer's theory is that it explains how the Supreme Court itself views the criminal justice process. The weaknesses of Packer's theory are also the weaknesses of the Supreme Court's conception of the criminal justice system.

Packer's theory fell out of favour in the United States ${ }^{17}$ precisely because it does not encompass victims' rights or community rights. ${ }^{18}$ The problem with the theory is that it is too simplistic and that it ignores the more complex reality of multiple interests involved in the justice system. A critic of Packer has argued that

any analysis of organizational behaviour must be open-ended enough to identify and deal with the multiplicity of goals, values and incentives of the various actors comprising the system. To do otherwise is likely to lead into the trap of reification and away from social theory. ${ }^{19}$

Packer articulated his theory before victims' rights groups had become powerful as a political force in Canadian society. ${ }^{20}$ However, Packer's theory provides a framework within which to view the Supreme Court's decisions. Like Packer's theory, the Supreme Court created its exclusionary rule within a narrow liberal ideology that failed to consider as relevant the security or equality rights of victims. ${ }^{21}$

\section{B. COMmon LaW PRINCIPLes}

One of the key factors in the development of a quasi-automatic exclusionary rule was the Supreme Court's expansion of the concept of self-incrimination. In order to understand the extent to which the Court has departed from the common law principles, it is necessary to examine the development of a number of those principles: the confessions rule, the privilege against self-incrimination, and the right to silence. The choices that the Supreme Court has made among these principles has led to the development of an exclusionary rule that does not reflect either the intent of Parliament or the wording of the section itself. ${ }^{22}$ Instead, the Supreme Court has developed a rule that is faithful to a legal-liberalist perception of the criminal justice system.

At common law, the starting point for any discussion of the admissibility of evidence was the presumption that all evidence that was relevant, probative and reliable would

16. Roach, supra note 11 at 24.

17 Ibid. at 20.

is The term "community" here is defined to mean any subgroup within Canadian society.

14 M. Feeley, "Two Models of the Criminal Justice System: An Organizational Perspective" (1973) 7 L. \& Soc. Rev. 407 at 415.

211 Roach, supra note 11 at 20.

$21 \quad$ Ibid. at 24.

22 D.M. Paciocco, "The Judicial Repeal of s. 24(2) and the Development of the Canadian Exclusionary Rule" (1990) 32 Crim. L.Q. 326 [hereinafter "Judicial Repeal"]. 
be admitted in court. ${ }^{23}$ If evidence was ruled inadmissible, it was generally because the evidence was either unreliable or of low probative value. ${ }^{24}$ The confessions rule was an example of evidence that was excluded because of reliability concerns.

The rationale for the confessions rule was the concern that a statement that was made in conditions where the accused either hoped for an advantage, or feared some prejudice, might be unreliable, and that the courts ought not admit a potentially unreliable statement. This rationale was outlined clearly in $R$. v. Towler, where McFarlane J. of the British Columbia Court of Appeal stated:

the true ratio of decisions which have held such statements inadmissible and the real basis for exclusion is the danger that they may be untrue. In other words, it was argued, it is the untrustworthiness of confessions made as a result of inducements which provides the real basis or reason for the rule of law which protects an accused person from their being used against him. ${ }^{25}$

Whereas concern about reliability was the key rationale for the confessions rule, there are a number of different rationales given for the privilege against selfincrimination. One of the most common is the principle that the state could not put an individual's liberty at risk merely on the basis of suspicion or a bald accusation. ${ }^{26}$ The state has to be in a position to produce some evidence of the stated offence and the accused could not be required, from his or her own mouth, to produce that evidence. This rationale grew out of the historical origin of the privilege. ${ }^{27}$ Various procedures were developed in answer to this principle and can be summarized by the concept of "a case to meet." ${ }^{28}$ The preliminary hearing, the fact that the Crown presents its case first, and the fact that the Crown cannot split its case are all procedural examples of the principle of the case to meet. ${ }^{29}$ The privilege against self-incrimination, therefore, provides essentially that the accused cannot be compelled to testify, and that there is no need to testify or present evidence until such time as the Crown has provided a prima facie case.

The right to silence is a concept that is encapsulated in the Latin phrase, nullus tenetur seipsum prodere which roughly translates as "no one is bound to produce evidence against themselves." ${ }^{30}$ In a far more direct sense than in either of the other two principles, the right to silence embodies the idea that a suspect is in no way bound to co-operate with law enforcement agencies in putting together their case. ${ }^{31}$

D. Watt, Watt's Manual of Criminal Evidence (Toronto: Carswell, 2000) at 32. Ibid.

[1969] 2 C.C.C. 335 at 337.

E. Ratushny, Self-Incrimination in the Canadian Criminal Process (Toronto: Carswell, 1979) at para. 31 .

For a comprehensive discussion of the origins of the confessions rule, the right to silence and the privilege against self-incrimination, see R.H. Helmholz, et al., The Privilege Against SelfIncrimination: Its Origins and Development (Chicago: University of Chicago Press, 1997).

Ratushny, supra note 26 at 179.

Ibid.

Ibid. at 169.

Ibid. at 185. 
The interplay between the confessions rule, the privilege against self-incrimination and the right to silence are complex. In fact, commentators will often use the terms interchangeably. ${ }^{32}$ Scholars sometimes refer to the confessions rule as part of the right to silence. ${ }^{33}$ The non-compellability of an accused at trial, which is an aspect of the privilege against self-incrimination, is frequently referred to as the accused's right to silence at trial. ${ }^{34}$ This confusion in terminology also means that there is confusion over the underlying rationales of the various principles. What is clear, however, is that each of these principles has given rise to procedural rules designed to reflect the principles. The confessions rule gave rise to the procedure of the voir dire which required the Crown to prove voluntariness beyond a reasonable doubt. The privilege against selfincrimination gave rise to the non-compellability of the accused, and the right to silence resulted in the development of the police caution. All of these procedures were designed to ensure that the accused received a fair trial. It is important to note that "a right to a fair trial" in this common law context means a right to procedural safeguards; it is not a substantive right. The advent of the Charter has seen the elevation of the "right to a fair trial" to the position of a quasi-substantive right. This change has impacted negatively on the truth-seeking function of the trial process.

\section{The Purpose of an Exclusionary Rule}

In a crime control model of the justice system, exclusion of evidence is unwarranted since it fails to achieve the truth-seeking goal of a criminal trial. In a due process model, exclusion of evidence is the primary tool used for protection of individual rights. The Supreme Court, through the exclusionary rule, has established a due process model for the Canadian criminal justice system. The question remains, however, why the exclusionary rule is a necessary tool in the liberalist vision of the justice system. Although the Supreme Court, both before and after the advent of the Charter, expounded its belief that only exclusion of evidence could preserve the integrity of the justice system, there is no explanation given for why this must be so. There is also no exploration of the utility of any other rule. With section 24(2), the Charter has provided the Canadian justice system with the tool for the exclusion of evidence. In so doing, Parliament presupposed that exclusion of evidence was an appropriate and useful remedy for a breach of an individual's rights under the Charter. The justice system must use this tool, and the issues for discussion are when and why it should be used.

In his article, "Remedies for Non-Compliance with Investigative Procedures: A Theoretical Overview," ${ }^{35}$ Kenneth Jull sets out three basic goals of providing remedies for constitutional breaches. These are "compensation for the victim, deterrence of future

32 D.J. Galligan, "The Right to Silence Reconsidered" (1988) 41 Current Leg. Prob. 69 at 83, pointing out that one Australian judge in discussing the confessions rule used both the terms "privilege against self-incrimination" and "right to silence" as if they meant the same thing.

33 Ibid. at 80.

3 Thomson Newspapers v. Canada (Director of Investigation and Research. Restrictive Trade Practices Commission), [1990] I S.C.R. 425 at 599, 54 C.C.C. (3d) 417 [hereinafter Thomson Newspapers cited to S.C.R.]. 
violations and maintenance of the integrity of the legal system." ${ }^{36}$ In this context, Jull is using the term "victim" to mean the accused whose rights have been violated. These rationales will be examined in turn.

\section{A. VINDiCATION OF ACCUSED'S Rights}

Jull argues that exclusion of evidence is a valid approach to take where an accused's rights have been violated. He states that exclusion can serve the purpose of compensating the accused, because the exclusion of evidence places the accused in the position that he would have been in but for the violation of rights. This approach assumes that there is a causal link between the violation and the evidence that was obtained. However, the requirement of a causal link creates problems with the vindication rationale for exclusion. As David Paciocco points out, this rationale comes into play only if evidence was in fact discovered as a result of the violation. ${ }^{37} \mathrm{He}$ also notes that critics of the vindication rationale have argued that it is not in fact the accused who requires a remedy, but rather the community whose norms have been transgressed. ${ }^{38}$ In fact, it is probable that the accused can never be compensated for the violation of his or her rights. It is not just the gathering of evidence that may be the consequence of a violation, it is the invasion of privacy or dignity that may in fact be the greater harm done. This type of harm cannot be made right with an exclusionary rule, because exclusion comes after the fact. ${ }^{39}$ Given that the Charter provides the exclusion of evidence as a tool for the Courts, whatever justification is used for the exclusion of evidence, it cannot be the vindication of the accused's rights.

\section{B. DEtERRENT FunCtion}

If the accused cannot realistically be compensated, then perhaps a more valid rationale for the exclusionary rule is deterrence. This approach has the advantage of attempting to ensure that there is no invasion of privacy or other psychological damage. For this rationale to be valid, exclusion must be effective as a deterrent to police misconduct; otherwise, there is no purpose to the act of exclusion. Jull notes that there have been a number of empirical studies done in the United States concerning the effectiveness of exclusion as a deterrent, but that the results are inconclusive. ${ }^{40}$

In Canada, the deterrent motive for excluding evidence was initially articulated by Laskin J. in the pre-Charter case $R$. v. Hogan: ${ }^{41}$

It may be said that the exclusion of relevant evidence is no way to control illegal police practices and that such exclusion merely allows a wrongdoer to escape conviction. Yet where constitutional guarantees are concerned, the more pertinent consideration is whether those guarantees, as

Ibid. at 525.

Paciocco, supra note 22 at 334 . This anomaly is also highlighted in the American case, Irvine $\mathbf{v}$. California, 347 U.S. 128 (1954), 74 S. Ct. 381, online: LEXIS (MEGA) at 136.

Paciocco, ibid. at 335.

Jull, supra note 15 at 532 .

Ibid. at 536.

[1975] 2 S.C.R. 574, (1974) 48 D.L.R. (3d) 427 [hereinafter Hogan cited to D.L.R.]. 
fundamentals of the particular society, should be at the mercy of law enforcement officers and a blind eye turned to their invasion because it is more important to secure a conviction. The contention that it is the duty of the Courts to get at the truth has in it too much of the philosophy of the end justifying the means; it would equally challenge the present law as to confessions and other out-of-Court statements by an accused. In the United States, its Supreme Court, after weighing over many years whether other methods than exclusion of evidence should be invoked to deter illegal searches and seizures in state as well as in federal prosecutions, concluded that the constitutional guarantees could best be upheld by a rule of exclusion. ${ }^{42}$

In this same decision Laskin J. makes it clear that, in his view, judicial discretion to exclude should balance only two sets of interests:

The choice of policy here [in pre-Charter common law] is to favour the social interest in the repression of crime despite the unlawful invasion of individual interests and despite the fact that the invasion is by public officers charged with law enforcement. Short of legislative direction, it might have been expected that the common law would seek to balance the competing interests by weighing the social interest in the particular case against the gravity or character of the invasion, leaving it to the discretion of the trial Judge whether the balance should be struck in favour of reception or exclusion of particular evidence. $^{43}$

It is important to note that the term "social interest" is used to denote the interests of society as an undifferentiated whole. There is no recognition of competing interests within society, nor that individual interests are not exclusively delineated by the individual who is charged with an offence.

The deterrent motive for exclusion has also been used in post-Charter cases. In $R$. v. Therens, ${ }^{44}$ the Supreme Court stated that the reason for excluding the breathalyser results following a breach of the right to counsel was that

[t]o do otherwise than reject this evidence on the facts and circumstances in this appeal would be to invite police officers to disregard Charter rights of the citizen and to do so with an assurance of impunity. ${ }^{45}$

The deterrent rationale has been used more extensively in the United States, but the drawbacks to this approach have been identified in their jurisprudence. In Bivens v. Six Unknown Named Agents of Federal Bureau of Narcotics, ${ }^{46}$ Burger C.J. of the United States examined the rationale behind the American exclusionary rule. He stated that the primary rationale set out in American case law was deterrence of the use of illegal investigatory methods. ${ }^{47}$ However, Burger C.J. notes that if an alternative remedy to

Ibid. at $\mathbf{4 4 2}$.

Ibid.

[1985] I S.C.R. 613, 18 C.C.C. (3d) 481, [1985] S.C.J. No. 30, online: QL (SCJ) [hereinafter Therens cited to S.C.J.].

Ibid. at para. 11.

403 U.S. 388, 91 S. Ct. 1999 (1971) [hereinafter Bivens].

lbid. at 413 . 
the exclusionary rule is available, then "concern for official observance of the law does not require adherence to the exclusionary rule." ${ }^{.48}$ Finally, he says,

[s]ome clear demonstration of the benefits and effectiveness of the exclusionary rule is required to justify it in view of the high price it extracts from society - the release of countless guilty criminals. $^{49}$

Chief Justice Burger then calls for the replacement of the exclusionary remedy with a different and more flexible administrative remedy. ${ }^{50}$ Despite the lack of support for the theory that court decisions influence police procedures, this rationale remains one of the most enduring explanations for the exclusionary rule in the United States.

If the deterrent rationale is "conceptually sterile and practically ineffective," the only alternative left is the theory that exclusion of evidence protects the integrity of the process and the reputation of the justice system.

\title{
C. INTEGRITY OF THE SYSTEM
}

The theory that the exclusionary rule protects the integrity of the legal system rests on the assumption that judges should not be seen to ignore, or worse, collude in illegal investigatory methods by admitting evidence that is the fruit of such illegal activity. Jull examines this justification for the exclusionary rule and notes:

Evidence obtained through the violation of procedural rules creates a major problem for officials concerned with the integrity of the criminal justice system. The introduction of illegally obtained evidence into court may taint the entire process. This concern with the integrity of the system is illustrated in the early American cases which reflect not only the "reason and truth" but also the teleological goal of promoting greater respect for the law itself. ${ }^{52}$

The problem with this theory is that it assumes that the integrity of the system will be viewed negatively by the public who are the users of the system if the evidence is admitted, but will enhance the integrity of the system in the eyes of the public if the evidence is excluded. This is a debatable assumption. ${ }^{53}$ In $R$. v. Collins, ${ }^{54}$ Lamer J. observed that it was quite possible that damage to the integrity of the justice system could result from the exclusion of evidence. A second problem associated with this rationale for the exclusionary rule is that it relies heavily on the personal views of the judges as to precisely how the integrity of the system is affected by the exclusion of evidence. As Jull puts it:

\author{
Ibid. at 414 . \\ lbid. at 416. \\ lbid. at 422. \\ Ibid. at 415 . \\ Jull, supra note 15 at 542 . \\ Paciocco, supra note 22 at 337. \\ (1987), 5 C.C.C. (3d) 1, [1987] S.C.J. No. 15, online: QL (SCJ) [hereinafter Collins cited to \\ S.C.J.].
}


[i]f one identifies with a suspect, compensation for the violation of rights seems natural; if one empathizes with a potential victim, one would not want effective police work to be thwarted by purely technical non-compliance with complex procedural rules. ${ }^{55}$

Jull goes on to note that since the Charter itself does not make it clear where the balance is to be drawn, a "theory of justice" is required. ${ }^{56}$ The United States Supreme Court has stated that the exclusionary rule is based on

a belief that if a trial court looks the other way and ignores the unconstitutional manner in which the evidence in question is secured then the courts would be sanctioning "a manifest neglect if not an open defiance of the prohibitions of the Constitution." The belief was that through such silence the courts would become a party to the illegality and help to make it a fundamental right without a remedy. ${ }^{57}$

The Supreme Court has never articulated a clear rationale for the exclusion of evidence. They have generally linked the exclusion of evidence to the integrity of the justice system, but they have also flirted with the deterrence of police rationale as well.

In Collins, the Court stated that "s. 24(2) is not a remedy for police misconduct." Instead, the Court held that what is at issue is "the further disrepute [that] will result from the admission of evidence that would deprive the accused of a fair hearing, or from judicial condonation of unacceptable conduct by the investigatory and prosecutorial agencies." ${ }^{58}$ This statement places the rationale for exclusion into the category of the integrity of the system.

Other statements from the Court have served to cloud the issue, however. In $R$. v. Genest, the Court held that, "[w]hile the purpose of s. 24(2) is not to deter police misconduct, the courts should be reluctant to admit evidence that shows the signs of being obtained by an abuse of common law and Charter rights by the police." decision, it seems as if the Court is both rejecting and endorsing police deterrence as the basis for excluding evidence. In $R$. v. Duguay, ${ }^{60}$ the Supreme Court upheld the Ontario Court of Appeal's decision that evidence should be excluded where the police had detained the three accused, but had not advised them of their rights to counsel. At the Court of Appeal, Zuber J. wrote a strong dissent examining the purpose of s. 24(2). Justice L'Heureux-Dubé of the Supreme Court also dissented, and reviewed the approach taken to the exclusion of evidence. After quoting at length from Zuber J.'s decision, she turned to an analysis of the connection between the violation of a right and the exclusion of evidence. She noted that the accused

must bring the court to consider the interplay between the seriousness of the violation, the fairness of the trial and the effect of exclusion. In this context, courts are sometimes pressed to exclude the

Ibid.

Katz, supra note 4 at 115, quoting Weeks v. United States, 232 U.S. 383, 34 S. Ct. 341 (1914), online: LEXIS (MEGA), footnotes omitted. 
evidence pursuant to s. 24(2) of the Charter because to admit it would condone the underlying violation. Courts are thereby invited to use the remedy of exclusion to discipline improper police conduct. Such an argument, if accepted, would greatly reduce the applicant's burden under s. 24(2). As every breach of the Charter is serious and as no court wishes to condone improper police conduct, the argument provides the means to avoid engaging in any sort of balancing. Taken to its logical extreme, this reasoning leads to the automatic exclusion of evidence.

In my view, the blind-eye reasoning is based on the incorrect assumption that a decision not to exclude pursuant to s. 24(2) of the Charter means that the court condones the underlying violation. The equation, however, does not necessarily follow. There may be, in certain cases, "particular circumstances [which] provide a rational basis for holding that the admission of the evidence will at least give the appearance of condoning misconduct"... Such circumstances would be relevant in the application of s. 24(2). Other than these special cases, it would be, in my view, incorrect to assume that admitting the evidence condones the underlying infringement. Moreover, as held by this court in Collins and Genest, it is generally not proper for a court to exclude evidence with a view to controlling the police. The main reason for this is that the price of exclusion is not paid by the police, and that consequently, from the police's point of view, exclusion generally would amount to no punishment at all. The public and the victims of the offence are those who are affected by the exclusion. For these reasons, I am of the view that the blind-eye reasoning is inconsistent with a proper interpretation of s. $24(2) .^{61}$

This analysis highlights the problems of linking police misconduct to the integrity of the justice system. This purpose, as has already been noted, is problematic. First, because there is little evidence that court decisions have any impact on police conduct, and second, because it provides too inflexible a standard. ${ }^{62}$ As Burger C.J. noted in the Bivens decision, if the violation of rights is sufficient reason in itself for exclusion, inadvertent errors are treated in the same way as deliberate and flagrant behaviour. ${ }^{63}$ This approach could lead to the belief that offenders "get off" on technicalities, and does little to enhance the credibility of the justice system.

The Supreme Court does not, however, seem to appreciate the problems associated with the failure to clearly elucidate the foundation for excluding evidence, nor with the fact that both approaches that they have used have serious flaws. In $R$. v. Burlingham, the Court states, "[i]t must be emphasized that the goals of preserving the integrity of the criminal justice system as well as promoting the decency of investigatory techniques are of fundamental importance in applying s. 24(2)." ${ }^{64}$ Both deterrence and the integrity of the system are used as justifications for excluding the evidence in that case.

(1) Ibid. at 24-25 [citations omitted].

(2. Jull, supra note 15 at 536 . See also at 532, where empirical studies in the United States were shown to be inconclusive.

(1.) Bivens, supra note 46 at 418 .

[1995] 2 S.C.R. 206, 97 C.C.C. (3d) 385, [1995] S.C.J. No. 39, online: QL (SCJ) at para. 50, [hereinafter Burlingham cited to S.C.R.] [emphasis added]. 
At no point in the discussion concerning the rationale for the exclusion of evidence does the Court explain why exclusion, as opposed to other methods of preserving the integrity of the system, is to be preferred. As early as $R$. v. Hogan, Laskin J. had stated that he saw, "no practical alternative to a rule of exclusion." 65 He does not, however, explore alternatives and indicate why exclusion is the only viable option.

Before the advent of the Charter, there were not many options available and those that were available were not particularly successful. ${ }^{66}$ The Charter, though, contains s. 24(1) which states that the courts can provide, "such remedy as the court considers appropriate and just in the circumstances." Despite the fact that s. 24(1) leaves the door wide open to craft any kind of remedy that the Courts may find appropriate in the circumstances, the Supreme Court has relied almost exclusively on the exclusion of evidence under s. 24(2) without ever saying why this approach is the most appropriate one.

\section{The DeVelopment of THE EXClusionary Rule}

The Supreme Court in Collins suggested that the purpose of s. 24(2) was ultimately to preserve the integrity of the justice system by excluding evidence when necessary. The Court also articulated a three-part test for the exclusion of evidence. Evidence would be excluded if

- the admission of the evidence would affect the faimess of the trial,

- the evidence had been obtained in a manner that infringed or denied a Charter right, and

- the admission of the evidence would bring the administration of justice into disrepute.

The language of s. 24(2) is clear. It requires a balancing of interests. The section requires that evidence obtained as a result of a breach will be excluded, but only if, after a consideration of all the circumstances, the admission of the evidence would bring the administration of justice into disrepute. However, the path that s. 24(2) would take was determined even at this very early stage.

\section{A. The Admission OF THE Evidence Would AFFECT THE FAIRNESS OF THE TRIAL}

In Collins, Lamer J. outlined a number of factors that would impact the decision whether to exclude evidence or not. He then organized these factors into the three-part test noted above. The factors listed in the first branch of the Collins test were factors said to affect the fairness of the trial. With respect to the first group of factors, the judge had the following to say:

(*) D. Stuart, Charter Justice in Canadian Criminal Law (Toronto: Carswell. 1991) at 377-78. 
It is clear to me that the factors relevant to this determination [the impact on the fairness of the trial] will include the nature of the evidence obtained as a result of the violation and the nature of the right violated and not so much the manner in which the right was violated. Real evidence that was obtained in a manner that violated the Charter will rarely operate unfairly for that reason alone. The real evidence existed irrespective of the violation of the Charter and its use does not render the trial unfair. However, the situation is very different with respect to cases where, after a violation of the Charter, the accused is conscripted against himself through a confession or other evidence emanating from him. The use of such evidence would render the trial unfair, for it did not exist prior to the violation and it strikes at one of the fundamental tenets of a fair trial, the right against self-incrimination. Such evidence will generally arise in the context of an infringement of the right to counsel.... The use of self-incriminating evidence obtained following a denial of the right to counsel will generally go to the very fairness of the trial and should generally be excluded. ${ }^{67}$

Two issues are immediately apparent in reading this excerpt. The first issue is that the Court is classifying certain constitutional rights as more important than others. The second issue that leaps out is that the determination of the type of evidence is going to have a major impact on whether it is excluded.

\section{HIERARCHY OF RIGHTS}

The Supreme Court in Collins created a hierarchy of rights. Initially, it is difficult to see why the Court would come to the conclusion that the right to counsel was a more important right than the right to be free of unreasonable search and seizure. The latter involves an invasion of privacy, the former does not. It becomes easier to understand this classification system when one looks at the situation through the eyes of a liberal democratic ideologue. From this perspective, the accused is seen as standing alone against the immense power of the state. The rights that the accused possesses can only be fully realized if she has a champion by her side; someone familiar with the system who can control the inevitable excesses of the state - a lawyer ${ }^{68}$ The right to silence, in particular, is seen as only being a tangible right if the accused has a lawyer to insist that silence, in fact, be maintained. ${ }^{69}$ The defence counsel is seen as a necessity for an accused's right to silence to be effective. As John Langbein has noted,

the privilege against self-incrimination is an artifact of the adversary system of criminal procedure. Only when the modern "testing the prosecution" theory of the criminal trial displaced the older "accused speaks" theory did the criminal defendant acquire an effective right to decline to speak to the charges against him. The historical bearer of the new criminal procedure was defense counsel, who crept into the ordinary criminal trial almost unnoticed and who then worked a procedural revolution with consequences that still reverberate through Anglo-American criminal justice." 
Although liberalists would regard the right to privacy as important, they would also insist that rights are meaningless unless the individual is familiar with all the intricacies of those rights and that only a lawyer can be relied upon to ensure that the accused's rights are not just statements, that they are also effectual. Viewed in this light, it comes as no surprise that the Supreme Court would take the position that it did in Collins. In creating a hierarchy of rights and placing the right to counsel at the top of that hierarchy, the Court was seeking to protect the right to silence.

\section{DEFINITION OF SELF-INCRIMINATION}

At common law, the privilege against self-incrimination was created to protect the accused from being compelled to testify at trial. Linked to the privilege is the right to silence. The basic principle underlying this right is that the accused should not be obliged to speak to the police, but he may do so if he chooses. Self-incrimination, as a concept, only makes sense if what is being protected is the accused's testimonial evidence. ${ }^{11}$ All evidence in a criminal trial emanates from the accused, because it is the accused's actions that create the evidence. Whether it is the knife that the accused has bloodied or whether it is the DNA that the accused has left behind, it is the accused's interaction with the victim that creates the evidence. It is also clear that, with the exception of testimonial evidence, most evidence effectively pre-exists any Charter breach. Therefore, using Lamer J.'s description in Collins, the possibility exists that virtually any evidence could be considered self-incriminatory.

In Collins, the Court made a clear distinction between the impact that "real" evidence would have and the impact that "self-incriminatory" evidence would have. Selfincriminatory evidence was held to be evidence that constituted a confession or other evidence emanating from the accused. There was no precise definition of what "evidence emanating from the accused" meant. However, the first suggestion that this evidence would involve more than just testimonial evidence or evidence created by the accused, such as breathalyser readings, came in the decision of $R$. v. Leclair and Ross. $^{72}$

In that case, the two accused were arrested and charged following a break-in at a residence. They were given their rights to counsel and they each tried to telephone their lawyers. However, given that it was very late at night, they were unable to reach their respective counsels. Leclair was offered the opportunity to try and call another lawyer, but he declined. Some time later, the two were asked to participate in a line-up and they did so. ${ }^{73}$

At trial, Ross asked that the line-up evidence be excluded on the basis that his right to counsel had been denied. The matter ultimately went to the Supreme Court, which held that there had been a breach of s. 10(b) rights since there was no urgency in the

In this discussion, testimony at trial and pre-trial statements are both included under the rubric of "testimonial evidence."

72 [1989] I S.C.R. 3, 46 C.C.C. (3d) 129, online: QL (CRIM) [hereinafter Ross cited to C.C.C.].

Ibid. at 132 . 
matter of the line-up and the police could have waited until Leclair and Ross had, in fact, contacted their counsel. ${ }^{74}$ Then the issue turned to the exclusion of the evidence. The Court found that identity was "real" evidence in the sense that it pre-existed any Charter breach. However, the Court found that participation in the creation of credible line-up evidence was self-incriminatory evidence which affected the fairness of the trial. $^{75}$ The Court stated:

Any evidence obtained, after a violation of the Charter, by conscripting the accused against himself through a confession or other evidence emanating from him would tend to render the trial process unfair. In Collins we used the expression "emanating from him" since we were concerned with a statement. But we did not limit the kind of evidence susceptible of rendering the trial process unfair to this kind of evidence. I am of the opinion that the use of any evidence that could not have been obtained but for the participation of the accused in the construction of the evidence for the purposes of the trial would tend to render the trial process unfair. ${ }^{76}$

After this decision, self-incriminatory evidence included statements, evidence emanating from the accused, and any evidence that required the participation of the accused in the "construction" of the evidence.

This decision was followed by $R$. v. Mellenthin. ${ }^{77}$ In that case, an officer executed a traffic stop, asked the driver what was in the gym bag sitting on the front seat of the car and, when the driver opened the bag, the officer seized the drugs that were discovered. The Supreme Court stated that the search (request to open the gym bag) was unreasonable and since the drugs could not have been discovered "but for" that unreasonable search, their discovery would render the trial unfair and therefore they ought to be excluded. Although the drugs were "real" evidence, in this context the drugs were seen as self-incriminatory because they would not have been discovered "but for" the rights violation. After Mellenthin, the description of the type of evidence that was found to be self-incriminatory included statements, evidence emanating from the accused, any evidence that required the participation of the accused in the "construction" of the evidence, and evidence that could not have been discovered "but for" the rights violation.

In illustration of the extent of the shift in this definition of self-incriminatory evidence and its impact on the exclusionary rule, it is useful to return to the facts in Collins. In that case, the drugs in Collins' purse were admitted into evidence despite the unreasonableness of the search because the evidence was "real," and as the Court noted at the time, "real" evidence might operate unfortunately for the accused, but it would rarely operate unfairly. ${ }^{78}$ However, had the analysis in Mellenthin been used,

Ibid. at 135-38.

Ibid. at $139-40$.

Ibid. at 139.

[1992] 3 S.C.R. 615, [1992] S.C.J. No. 100, online: QL (SCJ).

Burlingham, supra note 64 at para. 79, quoting from Collins, supra note 54 at 288. 
the drugs in Collins would have been excluded. ${ }^{79}$ This analogy illustrates the extent of the expansion of the definition of self-incriminatory evidence.

In Burlingham, there is yet another expansion in the category of evidence that is considered self-incriminatory. The facts in Burlingham will be discussed in detail later in this article. Suffice to say that Burlingham stands for the proposition that any inculpatory evidence that is found "proximate" to the breach, regardless of whether the accused is conscripted in its discovery, will be excluded. ${ }^{80}$

The final case to be examined is $R$. v. Stillman.$^{81}$ In that case, Stillman was accused of murdering a young woman under a bridge, near a river. The police had very little evidence to go on, other than the facts that Stillman was seen with the deceased shortly before her death, and that sometime after her death he was seen in a wet and muddy condition. The police arrested Stillman and he retained counsel. His counsel sent a letter to the police stating that the accused would not supply any bodily samples. Notwithstanding this, the police took a number of bodily samples under threat of force. The police also interviewed the accused. He said nothing, but he cried throughout the interview and ultimately blew his nose and discarded the tissue. This tissue was seized by the police and sent along with the other samples for DNA testing. Stillman was arrested when the DNA results returned. ${ }^{82}$ At the time the samples were taken there was no way to take bodily samples other than by consent or as incident to an arrest because the Criminal Code amendments were not yet in force.

The Court rejected the argument that, though the samples were taken incident to the arrest, there had been no consent, and the bodily samples (other than the tissue) were found to have been an unreasonable search and seizure. The tissue was treated differently. The Court found that although the tissue had clearly been discarded by the accused, it had not been "abandoned." The accused therefore retained a privacy interest in the tissue:

[W] hen an accused person is in custody, the production of bodily samples is not an unforeseen occurrence. It is simply the inevitable consequence of the normal functioning of the human body. The police are only able to profit from the production of the samples because the accused is continuously under their surveillance. For this reason it is somewhat misleading to speak of "abandonment" in the context of evidence obtained from an accused in custody. ${ }^{83}$

The Court concludes by observing that although an accused loses some expectation of privacy after arrest, the privacy expectation in this case was not so low as to permit the seizure of the tissue. ${ }^{84}$

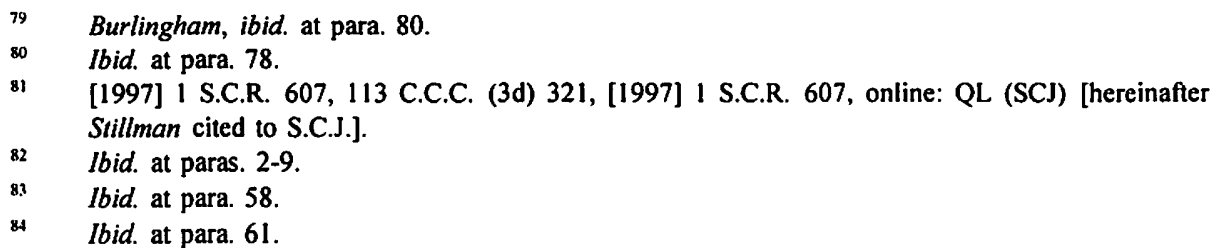


In keeping with the analysis in Mellenthin and Burlingham, the Court excluded the bodily samples on the basis that the accused was conscripted against himself to produce the samples. Although the Court could have stopped there, it went on to draw an analogy between testimonial self-incriminatory evidence and bodily samples. The Court stated:

It has, for a great many years, been considered unfair and indeed unjust to seek to convict on the basis of a compelled statement or confession. If it was obtained as a result of a breach of the Charter its admission would generally tend to render the trial unfair. Similarly, to compel an accused to use his body or to provide bodily substances in order to incriminate himself would generally render the trial unfair. This is so because the compelled production of bodily parts or substances is just as great an invasion of the essence of the person as is a compelled ... statement. The unauthorized use of a person's body or bodily substances is just as much compelled "testimony" that could render the trial unfair as is a compelled statement. ${ }^{85}$

This statement reflects a misunderstanding of the principles underlying the original concept of self-incrimination. The reason why a compelled (non-voluntary) statement from an accused was felt to render a trial unfair was not because of the invasion of privacy, but because of the concern that it might be unreliable. There is very little issue concerning the reliability of DNA evidence obtained from bodily substances, nor is there any issue concerning the reliability of body parts (fingerprints and so on). There is an issue concerning expectation of privacy, but that is separate from the principles underlying testimonial self-incrimination and the two ought not to be combined. The Court, in this statement, has created an analogy between testimonial self-incriminatory evidence and bodily substances that is not warranted by the rationale against testimonial self-incrimination. In so doing, it has once again expanded the concept of selfincrimination.

In her dissent in Stillman, McLachlin J. signals concern about the expansion of the concept of self-incrimination. The majority in that decision had determined that the seizure of bodily substances (hair, buccal swabs, and dental impressions) had violated s. 7 of the Charter on the basis that the seizure offended the privilege against selfincrimination. Section 7 mandates a fair trial as a principle of fundamental justice. Therefore, if the seizure violated s. 7, it also inevitably rendered the trial unfair. Given that under the s. 24(2) analysis, any evidence that renders the trial unfair must be excluded, the samples were excluded as a matter of course. ${ }^{86}$

Justice McLachlin notes that the original common law principle of self-incrimination applied only to testimonial evidence and that the courts had consistently resisted any attempt to enlarge the principle to include real evidence that had come from the accused. She also states that, unlike the specific ss. 8-14 of the Charter, s. 7 refers only to the principles of fundamental justice, and that section must refer to those principles as they exist in the common law. Therefore, insofar as the privilege against self- 
incrimination is subsumed within s. 7 , it can only be the privilege as it existed in common law - that is to say, a privilege relating to testimonial evidence.

The rationale underlying the privilege against self-incrimination - that the accused should not be forced to condemn himself with his own words - does not exist in the context of real evidence. Justice McLachlin therefore concludes that

[t]o render illegal the compelled use of the accused's body in gathering evidence against the accused would be to render inadmissible many kinds of evidence which have long been routinely admitted. The identification witness who says, "I recognize the man in the prisoner's box as the person I saw at the scene of the crime," is using the accused's body against him. Standard police techniques such as photographing the accused or requiring him to appear in an identification line-up similarly depend on using the accused's body against him, usually without consent. The principle against self-incrimination provides no means to distinguish between the police photo and more serious incursions of the suspect's body. The principle of protection against unreasonable search and seizure, on the other hand, provides such means. The principle against self-incrimination applied to physical evidence is a blunt tool, requiring either distortion or supplementation if it is to operate fairly and practically. The principle against unreasonable search and seizure, by contrast, evokes a body of jurisprudence aimed at aiding the court in making the necessary distinctions between permissible use of the suspect's body and impermissible use of the suspect's body. ${ }^{87}$

Justice McLachlin therefore makes clear, in her dissent, that it is inappropriate to use s. 7 as a vehicle to deal with the issue of bodily integrity. The other consequence of narrowing the definition of self-incriminating evidence to testimonial evidence would be to sever the link between many types of evidence that are currently held to be "selfincriminatory" and the first branch of the Collins test that almost always requires exclusion. Such evidence would have to be assessed under the second and third branches of the test which require an assessment of the seriousness of the breach and the impact of the admission of the evidence on the administration of justice.

Once the Court has found that the evidence is self-incriminatory, under the Collins test, the evidence is almost always excluded. If the Supreme Court had chosen to restrict the type of evidence that was considered "self-incriminatory," then evidence would only rarely have been excluded. By widening the definition of "selfincriminatory," the Court succeeded in increasing the possibility that evidence would be excluded.

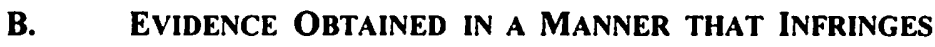 OR DENIES A RIGHT OR FREEDOM}

The other factor that has contributed toward effectively creating a quasi-automatic exclusionary rule was the definition of "evidence ... obtained in a manner that infringed or denied" a Charter right. In $R$. v. Strachan, ${ }^{88}$ the Supreme Court established the

[1988] 2 S.C.R. 980, 46 C.C.C. (3d) 479, online: QL (CRIM) [hereinafter Strachan cited to C.C.C.]. 
requirement that the connection between the Charter breach and the collection of evidence be temporal. In other words, if there was a breach of a Charter right then any evidence gathered after that breach could potentially be excluded. The Court rejected any requirement for a causal connection between the breach and the evidence collected. It also rejected a requirement for some nexus between the breach and the evidence. The Court did not come to this point quickly, and in fact, the Court considered both the causal connection test and the "some nexus" test before settling on the temporal connection.

In $R$. v. Therens, ${ }^{89}$ the Supreme Court had touched briefly on the question of what was meant by "evidence [that] was obtained in a manner that infringed or denied any rights or freedoms guaranteed by the Charter." Justice Lamer, for the majority, held that the phrase required that there

must not only exist a violation of a Charter right, but there must also be, as was said by Le Dain, J., "some connection or relationship between the infringement or denial of the right or freedom in question and the obtaining of the evidence the exclusion of which is sought by the application. With respect, however, 1 cannot subscribe to the proposition later advanced by Le Dain, J. that this requirement is met by the simple fact that the infringement or denial of the right has preceded the obtaining of the evidence. Indeed, if there is no relationship other than a temporal one, the evidence was not "obtained in a manner that infringed" the Charter. ${ }^{90}$

Justice LeDain, in dissent, stated that while there must be some connection between the breach and the obtaining of the evidence, that connection should be temporal. His logic was that, "[s]uch a view gives adequate recognition to the intrinsic harm that is caused by a violation of a Charter right or freedom, apart from its bearing on the obtaining of evidence." $"$

The Supreme Court dealt with the issue again in $R$. v. Upston, ${ }^{92}$ a one-page judgment dealing with a breach of the right to counsel. It appears from the judgment that after the breach occurred, the accused was advised of his right to counsel and then voluntarily supplied information to the police. The Court stated that, in those circumstances, "[t]he evidence adduced was not obtained as a result of that breach." 93 This statement would suggest that for evidence to be excluded, there must be a causal connection between the breach and the acquisition of the evidence.

The matter would be laid to rest in Strachan. Justice Dickson, speaking for the majority, rejected the requirement for a causal connection:

In my view, all of the pitfalls of causation may be avoided by adopting an approach that focuses on the entire chain of events during which the Charter violation occurred and the evidence was obtained.

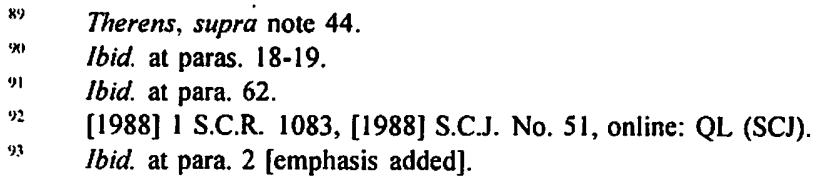


Accordingly, the first inquiry under s. 24(2) would be to determine whether a Charter violation occurred in the course of obtaining the evidence. A temporal link between the infringement of the Charter and the discovery of the evidence figures prominently in this assessment, particularly where the Charter violation and the discovery of the evidence occur in the course of a single transaction. The presence of a temporal connection is not, however, determinative. Situations will arise where evidence, though obtained following the breach of a Charter right, will be too remote from the violation to be "obtained in a manner" that infringed the Charter. ${ }^{94}$

It seems important at this stage to return to the actual language of s. $24(2) .^{95}$ That section requires that evidence be excluded if it was "obtained in a manner that infringed or denied a [Charter] right." The language itself requires a causal connection. Evidence that was obtained in a manner that infringed or denied a Charter right is evidence that it was acquired in an unconstitutional manner. The section requires that the question, "How was the evidence obtained?" be asked. If the answer is that the evidence was acquired as a result of a Charter breach, then the Court is to go on and consider the other requirements of s. 24(2). However, without actually referring to the language of the section, the Supreme Court states that a causal connection is too difficult a standard to require, ${ }^{96}$ and points out that "real" evidence would rarely be found to be causally connected to, for instance, a s. 10(b) breach. ${ }^{97}$ In so doing, the Court hits on the reason for choosing a temporal connection test rather than a causal connection test: the latter would limit the ability of the courts to exclude evidence. This view is reinforced by Dickson J.:

In my view, directing the initial inquiry in s. 24(2) to the existence of a causal connection between the Charter violation and the evidence whose exclusion is sought will encourage this type of restrictive approach to the rights and freedoms guaranteed by the Charter. ${ }^{98}$

It is one thing to define substantive rights in an expansive manner, but it is a different matter to define an enforcement provision in the same manner, and s. 24(2) is exclusively an enforcement provision. By eliminating the need for a causal connection between the breach and the evidence, the Supreme Court chose to expand the amount of evidence that could be brought within the protective ambit of s. 24(2). In so doing, the Court also ensured that a due process model of criminal justice, which would successfully hinder the truth-seeking trial process, is the paramount model in Canada.

\section{EVIDENCE That Would Bring the Administration OF JUSTICE INTO DISREPUTE}

The Supreme Court in Collins made two other important decisions that would affect the development of the exclusionary rule. Section $24(2)$ required that evidence be

Strachan, supra note 88 at $498-99$.

I am grateful to Professor Paciocco for a similar analysis set out in his article, "Judicial Repeal," supra note 22 at $346-49$.

Strachan, supra note 88 at 496.

Ibid. at 497.

Ibid. 
excluded only when it would bring the administration of justice into disrepute. The question then becomes, disrepute in whose eyes? In answering this question, the first thing that the Court did was substitute the word "could" for the word "would," thereby lowering the threshold for exclusion. This change was made on the basis that the French text used the phrase, "est susceptible de déconsidérer l'administration de la justice," which Lamer J. translated as "could bring the administration of justice into disrepute." 99 The next step taken by the Court was to decide that the public's perception of the administration of justice was not the standard by which the court would judge its own actions. Instead, the Court determined that the reputation of the administration of justice would be determined on the basis of "the reasonable man, dispassionate and fully apprised of the circumstances of the case." 100 The Court added that the reasonable man would be an average member of the community when that community's mood is reasonable. ${ }^{101}$ Finally, the Court stated:

The decision is thus not left to the [untrammelled] discretion of the judge. In practice, as Professor Morissette wrote, the reasonable person test is there to require of judges that they "concentrate on what they do best: finding within themselves, with cautiousness and impartiality, a basis for their own decisions, articulating their reasons carefully and accepting review by a higher court where it occurs." It serves as a reminder to each individual judge that his discretion is grounded in community values, and, in particular, long term community values. He should not render a decision that would be unacceptable to the community when that community is not being wrought with passion or otherwise under passing stress due to current events. ${ }^{102}$

As Paciocco points out, the effect of this approach was not to look to what the community's values are in determining when evidence should be excluded, but rather to ask judges to decide what the community's values should be. The impact of this decision is that,

judges in applying s. 24(2) of the Charter have a luxury that is not available elsewhere; they themselves get to define what conduct of theirs will bring them into disrepute. In so holding the court has done more than a litule violence to the concept of disrepute. ${ }^{103}$

Why did the Supreme Court feel that it was necessary to remove the actual views of the Canadian public from the equation? Was the reputation of the administration of justice in such poor shape that this move was necessary to preserve the integrity of the system?

Collins, supra note 54 at para. 43.

Ibid. at para. 33, quoting Yves-Marie Morissette in his article, "The Exclusion of Evidence Under the Canadian Charter of Rights and Freedoms: What to Do and What Not to Do" (1984) 29 McGill L.J. 521 at 538.

lbid.

Collins, supra note 54 at para. 34 .

Paciocco, supra note 22 at 343. 
To answer the second question first: according to Zuber J., there was nothing wrong with the reputation of the administration of justice. In his dissenting opinion in $R$. v. Duguay, ${ }^{104}$ Zuber J. wrote:

Granted that the Charter has changed the law but it has not overnight transformed the healthy repute of the administration of justice into a fragile flower ready to wilt because of the admission of evidence obtained as a result of a violation of the Charter rights of an accused. The regard of the Canadian public for the administration of justice prior to the Charter, despite the fact that evidence illegally obtained was admitted as a matter of course, was, in my view, very high. The repute of the administration of justice has not now suddenly become highly vulnerable. ${ }^{105}$

The Supreme Court effectively ignored this position and, as noted earlier, removed the public from the determination of the reputation of the administration of justice. The reason for this decision is probably found in the following statement by Lamer $\mathrm{J}$. in Collins, where he notes that, "[ $\mathrm{t}] \mathrm{he}$ Charter is designed to protect the accused from the majority, so the enforcement of the Charter must not be left to that majority." 106 So to answer the first question above, the reason why the public was removed from the equation was that the public's views could not be trusted. According to the Supreme Court, the "public" was part of that immense and powerful state against which the accused stood alone. As noted by Paciocco:

In a nutshell, the public does not appreciate the importance of fundamental rights and freedoms and it is therefore up to the courts to protect those rights and freedoms through the expedient of exclusion, notwithstanding the language of the Charter and notwithstanding what the public might think about it; the general purpose in having a Charter overrides the specific language of a particular provision. At the surface of all of this is ready acceptance of the same political philosophy that has sustained the American exclusionary rule for so many years. ${ }^{107}$

At each and every point that the Supreme Court could have decided in favour of broader societal interests, it has chosen instead to protect the individual. This decisionmaking process has ensured the triumph of liberalism and the loss of any balanced approach to the exclusion of evidence.

\section{Alternatives to the Present Rule}

In Burlingham, L'Heureux-Dubé J., writing in dissent, raises concerns about the direction that the exclusionary rule is taking in Canada. In particular, she notes that the Court is expanding the application of the first branch of the Collins test - the trial fairness branch. Given that the Court has already ruled that evidence which affects trial fairness should almost always be excluded, the impact of an expansive application of C.R.]. 
that branch of the test is to extend the categories of evidence that will be subject to almost automatic exclusion.

Justice L'Heureux-Dubé suggests a different approach to the exclusionary rule that, in her view, would result in a return to the spirit of s. 24(2). She suggests that evidence should be grouped into two categories, depending on whether a violation of Charter rights has resulted in the creation or discovery of unreliable evidence, or on whether the evidence is reliable. In accordance with common law principles, unreliable evidence would be excluded on the basis that its admission would affect the faimess of the trial. Reliable evidence that was discovered as a result of a violation of rights would be subject to scrutiny on the basis of the seriousness of the breach, the seriousness of the charge, its probative value in the case, and whether, in all the circumstances, its admission would bring the admission of justice into disrepute. This proposal by L'Heureux-Dubé J. was greeted with condemnation by her colleagues on the bench, one of whom suggested that this approach signalled a return to the pre-Charter crime control days. ${ }^{108}$

\section{The Costs of Exclusion}

In its development of the exclusionary rule, the Supreme Court has ensured that individual rights are paramount. In the discussion of the purpose of s. 24(2), it was noted that the Court has linked police misconduct to the integrity of the justice system and concluded that exclusion of evidence was required to maintain this integrity. However, it has also been noted that exclusion of evidence has not been shown to have any appreciable effect on police conduct. If the police are not actually paying the price when evidence is excluded, who is? It will be suggested in the next section that it is the victims who pay the price.

\section{A. General Principles}

In a due process model of criminal justice, victims' interests are not taken into consideration. Victims, like prosecutors and law enforcement authorities, are aligned with the state. A due process jurisprudence does not count the cost to victims because any cost is considered to be borne by the state. Perceived in this fashion, the acquittal of a few guilty parties is a small price to pay for the protection of individuals and the restriction on the power of the state.

Unfortunately, crimes are not committed against the state, they are committed against other individuals. Moreover, victims often come from disadvantaged groups in society, and it is the marginalized communities who are hardest hit by crime. Sexual assaults and domestic assault victims are overwhelmingly women and children. Victims of violent crime are equally often those from disadvantaged communities. ${ }^{109}$ This is not to suggest that crime is universally experienced by disadvantaged groups. Commercial 
crime and theft are more often committed against corporations. The point, however, is that the heaviest burden of crime is borne by the less advantaged in society.

The Charter was written in a fashion that would permit the conclusion that certain rights are available to both victims and offenders. Section 7 of the Charter reads:

7. Everyone has the right to life, liberty and security of the person and the right not to be deprived thereof except in accordance with the principles of fundamental justice. [emphasis added]

\title{
Section 15 reads,
}

15. (1) Every individual is equal before and under the law and has the right to the equal protection and equal benefit of the law without discrimination and, in particular, without discrimination based on race, national or ethnic origin, colour, religion, sex, age or mental or physical disability. [emphasis added]

The rights of victims and offenders clashed in $R$. v. Seaboyer. This case challenged the rape-shield provisions of the Criminal Code. ${ }^{110}$ The majority in that case decided that the rape-shield provisions contravened s. 7 and s. 11(d) - the presumption of innocence. In its judgment, the Court referred to the suggestion that victims might be included in the "everyone" named at the start of s. 7. Their response was as follows:

\begin{abstract}
A final point must be made on the ambit of $s .7$ of the Charter. It has been suggested that $s .7$ should be viewed as concerned with the interest of complainants as a class to security of person and to equal benefit of the law as guaranteed by ss. 15 and 28 of the Charter... Such an approach is consistent with the view that 5.7 reflects a variety of societal and individual interests. However, all proponents in this case concede that a measure which denies the accused the right to present a full and fair defence would violate $s .7$ in any event. ${ }^{111}$
\end{abstract}

Or, put another way, s. 7 applies to everyone unless an individual's interests come into conflict with the accused's rights, in which case they are no longer part of "everyone." The issue of whether a victim and the accused in a criminal trial could or should be offered equal protection of the law is not examined at all. International covenants to which Canada is a signatory would suggest that such an examination should have occurred. Both the International Covenant on Civil and Political Rights and the Convention on the Elimination of All Forms of Discrimination Against Women emphasize that the law should not operate so as to disadvantage women. ${ }^{112}$

R.S.C. 1985 , c. C-46.

R. v. Seaboyer, [1991] 2 S.C.R. 577, [1991] S.C.J. No. 62, online: QL (SCJ) at 603-604 [hereinafter Seaboyer cited to S.C.R.].

Article 3 of the International Covenant on Civil and Political Rights, 19 December 1966, 999

U.N.T.S. 171, Can. T.S. 1976 No. 47 states:

The State Parties to the present Covenant undertake to ensure the equal right of men and women to the enjoyment of all civil and political rights set forth in the present Covenant.

Article 2(c) of Convention on the Elimination of All Forms of Discrimination Against Women, 4 January 1969, Can. T.S. 1982 No. 31 states:

States Parties ... undertake: 
Justice L'Heureux-Dubé, dissenting in Seaboyer, also addresses the application of s. 7 to sexual assault complainants. She reviews cases that have acknowledged community interests in the justice system and then states:

Additional support for a broader analysis of the rights invoked by the appellants in this case can be found in s. 28 of the Charter. In the context of this case, this section would appear to mandate a constitutional inquiry that recognizes and accounts for the impact upon women of the narrow construction of ss. 7 and 11(d) advocated by the appellants.

While the exact nature of the other interests involved depends upon the nature and aspect of the right considered, it is clear from the above that the constitutional inquiry in this area is not confined to the narrow interest of the accused. ${ }^{1 / 3}$

This statement is an acknowledgement of the fact that where victims' rights and accused's rights come into conflict, some Charter rights mandate a balanced approach that accommodates, to the greatest extent possible, both interests.

The dissenting opinion in Seaboyer attempted to incorporate victims' interests into the interpretation of rights provisions. However, the case also stands for the proposition that, in any conflict, the accused's rights will take precedence. The conflict between victims' rights and the accused's rights was very clearly articulated in that decision. Victims' interests are less obvious in cases where the main issue is the exclusion of unconstitutionally obtained evidence.

Roach points out that victimization studies have shown that criminal activity generally is under-reported. He argues that this may be due to a sense that the criminal justice system is inadequate. If the criminal justice system is understood by the general public as enshrining individual rights to the exclusion of victims' interests, the tendency to under-report crime may continue. Roach also suggests that, if the justice system is seen as a failure, there are two possible responses. The first is to attempt to make the justice system more sensitive to victims' needs. The second is to move to a more community-based, restorative justice model. This second option is capable of addressing some of the underlying social causes of crime and can attempt to reconcile victims and offenders. ${ }^{114}$

The fact that the cost of excluding evidence is borne by victims was outlined in the Ontario Court of Appeal decision of Duguay. ${ }^{115}$ Justice Zuber, in a dissenting opinion, noted the following:

To establish legal protection of the rights of women on an equal basis with men and to ensure through competent national tribunals and other public institutions the effective protection of women against any act of discrimination.

Seaboyer, supra note 111 at 698-99.

Roach, supra note 11 at 26-37.

Duguay (C.A.), supra note 104. 
In my view the plight of the victim is also a relevant circumstance within s. 24(2). His dwelling was broken into and his possessions were stolen. He expended his time and energy by reporting the matter to the police, testifying at the preliminary hearing and apparently by attending at the trial ready to testify again. However, his recourse to the law has yielded him nothing. He no doubt has some interesting impressions as to the course of these proceedings.

The last circumstance to be considered is the effect of the exclusion of the evidence and, in this case, it is obvious that the exclusion of the evidence in question led to the collapse of the Crown's case. ${ }^{116}$

This judicial statement is one of the few that mention that the actual cost of excluding evidence is borne by the victims. In the next section, Burlingham is offered as an example of the impact that the exclusion of evidence can have on a case.

\section{B. BURLINGHAM - A SPECIFIC EXAMPLE}

The choice of Burlingham as an example of how the decision to exclude affects others in the criminal justice system besides the state is based partly on the seriousness of the charge and partly on the fact that it contains a very strong dissent from the Supreme Court.

As noted in the previous section, in a due process vision of the justice system victims become invisible. This fact is apparent from the outset of the Supreme Court judgment in Burlingham. Justice lacobucci begins his recitation of the facts in this fashion:

Terrence Burlingham, the appellant, is accused of the murder of Denean Worms, which was committed in October 1984 in Cranbrook, British Columbia. He has also been convicted of the murder of Brenda Hughes, which was committed in December 1984 also in Cranbrook. It was because of the very similar manner in which the two women were murdered and sexually assaulted that the police charged the appellant with the Worms murder at the point when it was decided to charge him with the Hughes murder. ${ }^{117}$

Contrast this recitation of the facts with the one that appears in the dissent in the same judgment:

In October 16, 1984, 20-year-old Denean Worms was found dead in a gravel pit in Cranbrook, B.C. She was naked, and had been shot twice in the head at contact range by a .410 shotgun. Semen was found in her vagina. On December 30,1984, also in Cranbrook, 16-year-old Brenda Hughes was found dead in her family house, murdered in a virtually identical manner. Terrence Burlingham was arrested on January 1,1985 in connection with the murder of Brenda Hughes. ${ }^{118}$ 
The majority's version sanitizes the facts of the deaths of both women. The horror of the crimes is lost.

Terrence Burlingham confessed to the murder of Brenda Hughes and was ultimately convicted of that murder. The police were convinced that Burlingham was also responsible for Denean Worms' death because of the similarity between the two offences, but they had no concrete evidence. They interviewed Burlingham at length, and all levels of court agreed that the interview was manipulative, inappropriate and constituted a serious breach of Burlingham's s. 10(b) right to counsel. Complicating the s. 10(b) issue was the fact that the police had offered Burlingham a "deal." The Crown had agreed that Burlingham could plead guilty to second degree murder if he gave the police a confession. What the police actually offered Burlingham however, was that he would only be charged with second degree murder if he confessed. There is no record of why the deal was changed, but the trial court found that it was a mistake and not a deliberate action.

The day after Burlingham confessed to Worms' murder and told the police where the gun could be found, he spoke to his girlfriend, Judith Hall. He told her that he had shown the police where the gun could be found and that he "knew something about the death of Ms. Worms." 119 Two months later, he also told Hall that he had been present when Worms was killed and that she had been beaten and killed, not by him but by his friend, Biddlecombe. The police had successfully recovered the gun, and the gun had been identified by Biddlecombe as one that he and Burlingham had stolen from a man named Lewis. Lewis also identified the gun as being one that had been stolen from him. The factual record outlined by the Supreme Court indicates that Worms was killed by a .410 shotgun, but does not reveal whether there was any other evidence linking the gun recovered by the police to the death of Worms. The only other evidence that the Crown had was circumstantial, and part of it was based on the similarity between the Hughes murder and the Worms murder. ${ }^{120}$

At trial, the judge excluded Burlingham's confession and the fact that he had shown the police where the gun had been thrown. However, he admitted the remaining evidence. At the British Columbia Court of Appeal, the majority upheld the trial judge's decision. In dissent, McEachern J.A. would have excluded the statement to Hall and the gun itself.

The majority of the Supreme Court overturned the Court of Appeal's decision and decided that, not only would they exclude the statement to Hall and the gun, but also the evidence of Biddlecombe and Lewis that they recognized the gun as being one that Biddlecombe and Burlingham had stolen. As well, the Supreme Court excluded the evidence that the police had recovered the gun. Thus, all evidence pertaining to the gun and tending to connect Burlingham to the murder weapon was excluded. This left the

\footnotetext{
11" Ibid. at para. 7.

121. This other evidence is outlined in the Court of Appeal decision but not referred to in the Supreme Court decision. See $R$. v. Burlingham (1993), 85 C.C.C. (3d) 343, [1993] B.C.J. No. 1986, online: QL (BCJ) at para. 58.
} 
Crown with the similar fact evidence of the Hughes murder and some other circumstantial evidence.

The police behaviour that led the Supreme Court to find a serious breach of the accused's s. 10(b) rights can be summarized as follows:

- the police denigrated Burlingham's lawyer and suggested that the lawyer's only real interest in Burlingham was in receiving money from him. This behaviour was found to undermine the solicitor-client relationship.

- the police continued to question Burlingham after he indicated repeatedly that he did not want to speak to them without first getting his lawyer's agreement.

- the police offered Burlingham a "deal" which involved him confessing in return for being charged with the lesser offence of second-degree murder. The police also indicated that this deal was time-limited, with the time limitation corresponding to his lawyer's expected return at the end of the weekend. This time limit effectively precluded Burlingham from speaking to the lawyer of his choice.

The method by which the Supreme Court comes to the conclusion that all of this evidence should have been excluded is interesting. The starting point for the s. 24(2) analysis is Strachan, which holds that a temporal connection between the breach and the gathering of the evidence was sufficient to meet the test in s. 24(2), unless the connection was too remote. The Court then goes on to find that the gun could not have been recovered by the police "but for" Burlingham's confession. Therefore, there was a direct connection between the illegally obtained confession and the recovery of the gun. ${ }^{121}$ The Court then goes on to elaborate an entirely new test for remoteness:

[I]t is appropriate to commence the consideration of what evidence should or should not be excluded from the trial process with the evidence obtained most proximate to the Charter breach and then work towards evidence arising more remotely therefrom.... [I]n terms of formulating this analysis, it must be kept in mind that there may be times (as in this case) where more remote evidence might not be admitted if its admission would have the same effect as admitting the most proximate evidence. ${ }^{122}$

In essence, this test for remoteness states that, where evidence is discovered after a violation of a Charter right and other evidence of a similar nature is also discovered, but is remote in time from the breach, the later evidence will also be excluded because it would prove the same fact as the evidence directly connected to the breach. This test makes a mockery of the concept of remoteness. It effectively prevents the Crown from introducing evidence discovered after a breach, but remote in time, if similar evidence was discovered proximate to the breach. It also means that a breach taints all evidence subsequently discovered. 
Biddlecombe and Lewis' identification of the gun is excluded presumably because, without the gun, there would have been nothing to identify. There is, however, no link between Biddlecombe and Lewis' evidence and any violation of Burlingham's rights. Even if the gun was excluded, the evidence of Biddlecombe that he had seen a .410 shotgun in Burlingham's possession could have been admitted, since that evidence was free of any relationship to the Charter breach. The new test for remoteness precluded this particular use of the evidence.

The Supreme Court also excluded the statement made by Burlingham to his girlfriend, Hall, the day after he had confessed to the police. The Supreme Court's justification for excluding a statement that they themselves admitted was entirely voluntary, and not made to a person in authority, was that

even though the statement may not have been "caused" directly by the breach, it was certainly made as a result of that breach. The statements to Hall flowed from the appellant's understandably confused state of mind stemming from the s. 10(b) violations and the critical decisions he had made in the absence of counsel. The appellant was still under the erroneous impression the "deal" was on. The statement was made the morning after the appellant had been unconstitutionally conscripted to provide evidence against himself. He had never been properly informed of his right to counsel and it cannot be said with any degree of conviction that he would have made the same statement to Hall had he been duly advised of his constitutional rights. In fact, he would have had nothing to say to Hall had he not been improperly conscripted to provide evidence against himself by the police in the first place. ${ }^{123}$

There was no evidence that the appellant's mind was confused as a result of the s. 10(b) violations. The Court had concluded that there had been a s. 10(b) violation and that the accused had confessed as a result of that violation, but there was no evidence that the accused was "confused." Given that the accused had consulted two lawyers and been told by both that he ought not to speak to the police and given that he confessed to the police despite this, Burlingham certainly could be considered to have poor judgment. Given also that the police behaviour directly contributed to Burlingham's poor judgment, it is easy to see why Burlingham's confession to the police would be excluded. However, what is not obvious is why the police's inappropriate behaviour, which elicited the confession, should somehow taint a statement made to Burlingham's girlfriend a day later and without any suggestion of inappropriate behaviour on the girlfriend's part. The statement to Hall was an "unanticipated windfall" for the Crown.

It is also difficult to understand the Court's comments that the accused had never been properly given his right to counsel, and that somehow this fact tainted the statement to Hall. There is no Charter right mandating that an individual be informed of his right to speak with counsel before speaking with his girlfriend. The only possible connection between Burlingham's confession to the police and his statement to Hall might have been that, having spoken to the police, there was no reason not to speak with Hall. The question remains, however, whether that is sufficient to justify excluding a voluntary statement in circumstances where the connection between the statement and the breach is so tenuous. 
The Supreme Court was not impressed with the conduct of the police in obtaining the confession from Burlingham. However, in its anxiety to exclude any evidence that had any connection, however tenuous, to that confession, it expanded, once again, the outer limits of self-incriminatory evidence and brought Canada ever closer to an automatic rule of exclusion. Several of the Court's statements in this regard are troubling. The first concerns the purpose of s. 24(2), and the second concerns the relationship between derivative evidence and the fairness branch of the Collins test. With respect to the purpose of s. $24(2)$, the Court makes two comments:

The purpose of this test [s. 24(2)] is to oblige law enforcement authorities to respect the exigencies of the Charter and to preclude improperly obtained evidence from being admitted to the trial process when it impinges upon the faimess of the trial. ${ }^{124}$

And,

[s] hort-cutting or short-circuiting those rights affects not only the accused, but also the entire reputation of the criminal justice system. It must be emphasized that the goals of preserving the integrity of the criminal justice system as well as promoting the decency of investigatory techniques are of fundamental importance in applying s. $24(2) .^{125}$

The Supreme Court has previously suggested that controlling or sanctioning police behaviour is not part of the function of s. 24(2), ${ }^{126}$ yet in this statement the integrity of the justice system is inextricably linked to police investigatory techniques. This linkage leaves no room for judgment concerning the degree of inappropriate behaviour, whether an honest mistake (as the problem concerning the "deal" was found to be in this case), or whether flagrant and deliberate (as the failure to ensure that the accused spoke to counsel about the "deal" was found to be). Both of these "mistakes" would be treated equally for the purposes of exclusion.

The second problem with the Court's treatment of the evidence in the Burlingham case is the manner in which all of the derivative evidence is placed into the first branch of the Collins test. Once evidence has been held to negatively affect the fairness of trial - the first branch of the Collins test - then exclusion almost inevitably follows. In the dissent in this case, the Court comments on the fact that, as a result of the broadening of the definition of self-incriminatory evidence, the balancing test set out in Collins is being narrowed to a test involving only the issue of the "fairness of trial." 127 The Court goes on to note that in this case, the category of self-incriminatory evidence has been expanded even further:

Iacobucci J.'s approach in the present case to take the definition of "trial unfairness" even one step further than ever before, moreover, by concluding as a matter of law that the "faimess of the trial" is adversely affected as a result of a "proximate connection" between the impugned evidence (i.e., the 
accused's voluntary statements to his girlfriend) and the s. 10(b) Charter violation. Each time the terminology has changed, it has expanded the scope of the first branch of the Collins analysis, and thereby increased the likelihood that virtually absolute exclusionary consequences will follow from a s. 24(2) analysis. ${ }^{128}$

In excluding the evidence in Burlingham, the majority comments that the Crown had a strong case, and acknowledges that the statement to Hall and the other evidence was very important to the strength of the Crown's case. The Court does not comment on the fact that, although the Crown still had a case against Burlingham, the evidence was now substantially weaker and the likelihood of conviction much reduced. The Court instead comments:

I realize that the appellant stands accused of a serious offence. However, as shall become evident in my disposition of this matter, the end result of allowing this appeal is not the issuance of a stay, but the ordering of a new trial in which the accused will have to meet the lawful evidence adduced against him. All that is required is the holding of the constitutionally mandated fair trial that should have occurred in the first place, and would have occurred were it not for the misconduct of the law enforcement agents. ${ }^{129}$

This new trial, of course, will take place without the most cogent, not to mention reliable, evidence that the Crown had in its possession. Reliability is not relevant, however, in the constitutional context. ${ }^{130}$ What is important is whether the evidence was obtained in an unconstitutional manner. This position reflects the fact that, as a result of the Supreme Court's development of the exclusionary rule, the trial is no longer a truth-seeking process. Instead, as would be expected in a due-process model, it is an investigation into whether evidence was obtained in a constitutional manner and whether individual rights were protected. ${ }^{131}$ The police, and not the accused, are on trial.

\section{Conclusion}

Packer's models of the criminal justice system provide a framework within which to examine the Supreme Court's approach to rights jurisprudence. At each and every point where the Court could have interpreted s. 24(2) so as to ensure a balancing of interests, it has instead chosen to enshrine the paramountcy of individual rights. The first branch of the Collins test required that any evidence found to be self-incriminatory would be excluded as tending to affect the fairness of the trial. That requirement, in and of itself, would not have precluded a balanced test, unless self-incrimination was given so broad a definition that virtually any evidence gathered as a consequence of a right violation could be excluded. 
In fact, that was exactly what happened. The common law had restricted the definition of self-incrimination to testimonial evidence because of two concerns. First, that there was something fundamentally abhorrent about making an individual speak to their own guilt. Second, that such evidence might be unreliable and therefore would be an unsound basis for conviction. Neither of these two concerns exist with other types of evidence. However, the Supreme Court decided to expand the definition of selfincrimination to include any evidence that the accused provided that was proximately connected to a violation of rights.

The Supreme Court could have restricted the amount of evidence that would be caught in the ambit of s. 24(2) by requiring a causal connection between the breach and any evidence obtained. Instead the Court required only a temporal connection. As a result of the Burlingham decision, it can be seen that the definition of remoteness has also been expanded to include any evidence that is related to other evidence discovered after a violation of rights. The Supreme Court has also insulated itself from any accountability to the public for the exclusion of evidence by deciding that the proper forum for deciding when the admission of evidence affects the administration of justice is the court itself. In this fashion, the Court can protect individual rights without having to concern itself with the possibly contrary view of the public.

Finally, the Supreme Court has never explained why exclusion of evidence is the only valid method of maintaining the integrity of the justice system, and why more imaginative remedies could not be crafted using s. 24(1). It has used the exclusionary rule to sanction police conduct and protect the integrity of the justice system without clearly exploring the justification for this approach. This last issue is perhaps the most important. By not properly examining the justification for using an exclusionary rule, the Supreme Court has avoided making explicit what is implicit in its rulings: that individual rights are paramount in any debate between the individual and the state. The Court has also avoided explaining why victims are included in the definition of state and why their interests are not deserving of protection. Instead, the Court has effectively linked any breach with the need to protect the integrity of the system. In so doing, it has turned s. 24(2) from a remedy that required a balancing of interests into a quasi-automatic rule of exclusion. The actual test applied by the Court can be articulated as follows: if there is a Charter breach, any evidence that is collected from the accused after the breach occurs, or is discovered as a result of the accused's participation in the investigation, is self-incriminatory; this will affect the fairness of the trial and the integrity of the justice system; therefore it must be excluded. There is no room in this test for any examination of the seriousness of the breach, nor for any examination of whether the consequences of exclusion are justified in the circumstances of the case.

The Supreme Court's approach to the enforcement of rights is predicated on its view of the justice system, and that view is based in legal liberalism. Using the exclusionary rule, the Supreme Court has created a justice system in which truth seeking has given way to an examination of police behaviour. The trial becomes not a search for the truth, but instead a process by which it is decided what truth will be admitted in evidence. The justification for this approach is the need to protect the individual against the state. 
Individual rights are indeed protected, but the price is paid by the victims, not the state. Given that the Canadian justice system has the exclusionary rule to use, it should be used in a manner that takes into account communitarian requirements as well as those of the individual. Only in that way will the victim's rights be protected along with those of the accused. Until then, the exclusionary rule will remain a triumph of liberalism. 